\title{
Prevalence of Rickettsia rickettsii infection in dogs from the urban and rural areas of western Turkey
}

\author{
Şükrü KIRKAN, Serap SAVAŞAN, Göksel ERBAŞ, Uğur PARIN \\ Adnan Menderes University, Faculty of Veterinary Medicine, Department of Microbiology, Aydın.
}

\begin{abstract}
Summary: In this study, rickettsial infections in dogs living in rural and urban areas were evaluated in the Western Turkey. Dog sera has been tested indirect immunofluorescence test (IFA) by containing Rickettsia rickettsii antigen. Dog blood sera samples were obtained from 250 dogs (50 dogs from urban area and 200 dogs from rural area) covering the two-year period between March 2009 - March 2011. For each sera, the antigen reactive with Rickettsia rickettsii constitute the end point titers were determined. A total of 250 dogs sera samples were tested. Dog sera samples were found 54.0\% (135/250) seropositive and 43.2\% (108/250) were found seronegative for the Rickettsia rickettsii. However, of the $2.8 \%$ (7/250 dog sera samples were found to be suspicious for the Rickettsia rickettsii at $\geq 1: 64-1: 256<$ titer. In this study, $7(14.0 \%)$ dogs in urban areas were found to be seropositive and 128 $(64.0 \%)$ dogs in rural areas were found to be seropositive in the $\geq 1: 256$ titer with the IFA test. In conclusion, titers of antibodies against Rickettsia rickettsii obtained from rural and urban dogs in Western Turkey appeared to be remarkable and more research needs to be done on this subject reveals.
\end{abstract}

Key words: Dog, IFA, Ricketsia rickettsii.

\section{Batı Türkiye'de kırsal ve kentsel alanlarında yaşayan köpeklerde Rickettsia rickettsii infeksiyonunun prevalansı}

Özet: Bu çalışmada, Türkiye'nin Batı Ege Bölgesi kırsal ve kentsel alanlarında yaşayan köpekler arasında riketsiya infeksiyonu değerlendirildi. Köpek serumlarına Rickettsia rickettsii antijeni içeren indirekt immunfloresan testi (IFA) uygulandı. Köpek kan serum örnekleri, Mart 2009- Mart 2011 dönemini kapsayan 2 y1llık periyotta 250 köpekten (50 köpek kırsal alandan ve kentsel alandan 200 köpek) elde edildi. Herbir serum için, Rickettsia rickettsii antijen ile reaksiyon oluşturan bitiş noktası titreleri belirlendi. Toplamda 250 köpek serum örneği test edildi. Köpek serum örneklerinin \% 54.0 (135/250)'ü Rickettsia rickettsii için seropozitif ve \% 43.2 (108/250)'si Rickettsia rickettsii için seronegatif bulundu. Bununla beraber, titresi $\geq 1: 64-<1: 256$ arasında olan köpek serum örneklerinin \% 2.8 (7/250)'i Rickettsia rickettsii için şüpheli bulundu. Bu çalışmada, IFA testi ile kentsel alandaki köpeklerden 7 (\% 14.0)'si $\geq 1: 256$ titrede seropozitif ve kırsal alandaki köpeklerden 128 (\% 64.0)' i $\geq 1: 256$ titrede seropozitif bulundu. Sonuç olarak, bu çalışma Türkiye'nin Batı Ege Bölgesi kırsal ve kentsel alanlarında yaşayan köpeklerde Rickettsia rickettsii etkenine karşı oluşan antikor titrelerinin önemli düzeyde olduğunu göstermiş ve bu konu ile ilgili daha fazla araştırma yapılması gerekliliği kanısına varılmıştır.

Anahtar sözcükler: IFA, köpek, Ricketsia rickettsii.

\section{Introduction}

Rickettsiae are Gram-negative, obligate intracellular bacteria in the family Rickettsiaceae and order Rickettsiales. The genus Rickettsia is distributed worldwide, with some species maintained in nature and transmitted to vertebrate hosts by arthropod vectors (21).

The genus Rickettsia has been classically divided into two groups, the typhus group (TG) and the spotted fever group (SFG), which have ticks as their major reservoirs (17).

The spotted fever group (SFG) unites a phylogenetically well-defined clade of Rickettsiae that are distinct from other species and that have a life cycle involving arthropods, mainly ticks (18). The SFG includes a number of pathogenic organisms that cause so- called tick-borne (TB) rickettsioses in humans. Rickettsia rickettsii (Rocky Mountain spotted fever, RMSF) and $R$. conorii conorii (Mediterranean spotted fever, MSF) are very important strains (19).

Ticks are usually thought to be the main reservoir and vectors of SFG Rickettsiae in nature, due to the ability of Rickettsiae to survive perpetually in ticks and to be transmitted transstadially and transovarially (19).

In the case of $R$. rickettsii and other spotted fever group rickettsiae, transfer of the infection from adult female to her eggs (transovarial transmission) supports infection of larval ticks, which is maintained past molting in the subsequent stages. Dogs are frequently exposed to ticks, and evidence of current or past infection in dogs can be used to determine whether there is a risk of 
infection with rickettsial tick-borne disease agents in a given geographic area $(2,4,6,16)$. All tick-borne pathogens are distributed focally within the ecologic landscape. Therefore documentation of infection in a dog, which presumably is more often in contact with ticks than humans, should prompt veterinary professionals to warn owners of an increased risk of tickborne diseases (14).

Infection with $R$. rickettsii, the causative agent of RMSF, induces an extremely severe, potentially fatal disease in people and in dogs. Indeed, among the tickborne diseases in the Americans, RMSF is the most severe, and can result in an acute-onset illness accompanied by a rapid course of disease and a high fatality rate. Mortality rates have been estimated at $20 \%$ in people in the absence of appropriate antibiotic treatment and $5 \%$ in patients who receive antibiotics. Canine patients present with fever, lethargy, vomiting and anorexia. As infection progresses, additional signs can develop in dogs, including ocular lesions, bleeding disorders, joint pain and neurologic abnormalities. Fatalities can occur in both people and dogs, particularly if appropriate anti-rickettsial treatment is delayed or never instituted (14). Dogs are usually subclinically infected, although more over disease has recently been reported (23).

The indirect immunofluorescence assay (IFA) is currently the test of choice for serologic diagnosis of rickettsial infection in humans and animals (10). In dogs, Rocky Mountain spotted fever is often diagnosed retrospectively by serology. A fourfold rise in titer in acute and convalescent samples taken more than three weeks apart is diagnostic. A single high titer may also be suggestive. Cross-reactions are seen with other spotted fever group Rickettsia. The indirect fluorescent antibody test is the most commonly used serologic test (25).

The aim of the present study is to investigate the prevalence of the Rickettsia rickettsii in dogs obtained from Western Turkey.

\section{Materials and Methods}

Materials: Dog blood sera samples were obtained from 250 dogs, living in urban (50 dogs) and rural (200 dogs) areas located in Western Turkey within 2 years of period from March 2009 to March 2011. Sampling was carried out in Aydın $(\mathrm{n}=90)$, İzmir $(\mathrm{n}=80)$ and Muğla $(n=80)$ provinces. Samples were collected from 2 years and over age owned dogs, living in urban and rural areas. The dog breeds used in this study were German Shepherd $(n=18)$, Kangal $(n=35)$, Pointer $(n=20)$, Setter $(n=22)$, Doberman $(n=12)$, Terrier $(n=20)$, and Mongrel $(n=123)$ (Table 1). Adnan Menderes University Local Ethical Committee of Animal Experiments stated no ethical penalty for this research with the decision of document number of 2009/54- December 30th 2009. None of the dogs examined showed clinical signs of acute infectious diseases, when the blood samples were collected. Blood samples then were brought to laboratory under the cold chain condition. After the seperation of sera from the total blood, sera samples were kept in deepfreezer at $20^{\circ} \mathrm{C}$, until the performance of IFA test.

Immunofluorescence Assay (IFA): IFA was performed with $R$. rickettsii antigen as previously described by the manifacturer's recommendation (Focus Diagnostics, Rickettsia IFA IgG, IF0100G). Sera were diluted in Phosphate Buffered Saline solution (PBS) and screened at the 1:64 dilution. Briefly, 10 microliters of diluted sera were added to each well of the antigen slides, the slides were incubated, washed, then incubated with fluorescein isothiocyanate-labeled goat anti-dog IgG with $1 / 100$ titer (Santa Cruz Biotechnology, Inc. sc-2436) and washed again. Test kit was recommended for humans, but IFA test was modified for dogs by using different conjugates. At the end, it was found that this conjugate that we used successfully worked. The slides were mounted with Gel Mount (Focus Diagnostics, Rickettsia IFA IgG, IF0007) under coverslips. The slides were read using an ultraviolet microscope (Leica DMLB; Leica Microsystems Wetzlar $\mathrm{GmbH}$, Germany) at $200 \times$ magnification. On each slide, a sera previously shown to be non-reactive (negative control) and a known reactive sera (positive control) were tested. The positive and negative sera samples were obtained from a project carried out by our coliques. Sera reacting at the screening dilution $(1: 64)$ were then tested in serial two-fold dilutions to determine the endpoint titer.

Table 1. The sampling provinces and distribution of dog breeds. Tablo 1. Örnekleme yapılan iller ve köpek ırklarına dağılımı.

\begin{tabular}{lcccccc}
\hline & \multicolumn{5}{c}{ Sampling Provinces } \\
Dog Breeds & Aydın & \multicolumn{2}{c}{ İzmir } & \multicolumn{2}{c}{ Muğla } \\
& R & U & R & U & R & U \\
\hline German Shepherd (n=18) & 3 & 3 & - & 4 & 2 & 6 \\
Kangal (n=35) & 12 & 2 & 7 & 1 & 12 & 1 \\
Pointer (n=20) & 2 & 3 & 4 & 3 & 6 & 2 \\
Setter (n=22) & 2 & 4 & 2 & 5 & 4 & 5 \\
Doberman (n=12) & 1 & 1 & 2 & 2 & 5 & 1 \\
Terrier (n=20) & 3 & 2 & 4 & 2 & 6 & 3 \\
Mongrel (n=123) & 52 & - & 44 & - & 27 & - \\
Total & $\mathbf{7 5}$ & $\mathbf{1 5}$ & $\mathbf{6 3}$ & $\mathbf{1 7}$ & $\mathbf{6 2}$ & $\mathbf{1 8}$ \\
\hline
\end{tabular}

R: Rural area, U: Urban Area

\section{Results}

In this study, a total of 250 dogs sera samples collected from Aydın, İzmir and Muğla provinces were examined by using IFA for Rickettsia rickettsia antigens. Overall, 54.0\% (135/250) of the dogs were seropositive and $43.2 \%(108 / 250)$ of the dogs were seronegative for Rickettsia rickettsii. In addition $2.8 \%$ (7/250) of the dogs with titer $\geq 1: 64-<1: 256$ were found to be suspected for Rickettsia rickettsii (Table 2). 
In this study, we found $7(14.0 \%)$ urban area dogs were seropositive with a titer of $\geq 1: 256$, and $128(64.0 \%)$ rural area dogs seropositive with a titer of $\geq 1: 256$ for Rickettsia rickettsii by IFA test (Table 3 ).

The results of IFA test for Rickettsia rickettsii in dog breeds according to the provinces investigated are given at Table 4.

Table 2. Interpreting the results of Rickettsia rickettsii by IFA test (Focus Diagnostics, Rickettsia IFA IgG, IF0100G)

Tablo 2. IFA testi ile Rickettsia rickettsii sonuçlarının değerlendirilme aralıkları

\begin{tabular}{|c|c|}
\hline $\begin{array}{c}\text { IgG Antibody } \\
\text { Titer }\end{array}$ & Titer Evaluation \\
\hline$<1: 64$ & No antibody detected \\
\hline$\geq 1: 64-<1: 256$ & $\begin{array}{l}\text { Single IgG sera endpoint titer } \geq 1: 64-<1: 256 \\
\text { are suggestive of infection at an undetermined } \\
\text { time and may be indicative of either past } \\
\text { infection or early response to a recent } \\
\text { infection }\end{array}$ \\
\hline$\geq 1: 256$ & $\begin{array}{l}\text { IgG sera endpoint titers of } 1: 256 \text { and greater } \\
\text { are considered preumptive evidence of recent } \\
\text { or current infection by organisms of the } \\
\text { appropriate Ricketsial antigen group }\end{array}$ \\
\hline
\end{tabular}

Table 3. The antibody titers by IFA for Rickettsia rickettsii antigen in the dogs

Tablo 3. Köpeklerde Rickettsia rickettsii antijelerine karş1 oluşan IFA antikor titreleri

\begin{tabular}{ccccc}
\hline Animal Sera & \multicolumn{4}{c}{$\begin{array}{c}\text { Number of seropositive animals according } \\
\text { to IFA test }\end{array}$} \\
& $<1: 64$ & $\geq 1: 64-<1: 256$ & $\geq 1: 256$ & TOTAL \\
\hline Urban Area Dogs & - & 5 & 7 & 12 \\
Rural Area Dogs & 2 & 128 & 130 \\
\hline
\end{tabular}

Table 4. Results of positive IFA test for Rickettsia rickettsii in dogs

Tablo 4. Köpeklerde Rickettsia rickettsii için pozitif IFA test sonuçları

\begin{tabular}{|c|c|c|c|c|c|c|}
\hline \multirow[b]{3}{*}{ Dog Breeds } & \multicolumn{6}{|c|}{$\begin{array}{c}\text { The number of seropositive dogs } \\
\text { for Ricketsia rickettsii }\end{array}$} \\
\hline & \multicolumn{2}{|c|}{ Aydın } & \multicolumn{2}{|c|}{ İzmir } & \multicolumn{2}{|c|}{ Muğla } \\
\hline & $\mathbf{R}$ & $\mathbf{U}$ & $\mathbf{R}$ & $\mathbf{U}$ & $\mathbf{R}$ & $\mathbf{U}$ \\
\hline German Shepherd $(\mathrm{n}=18)$ & 2 & - & - & - & - & - \\
\hline Kangal $(n=35)$ & 6 & - & - & - & 4 & - \\
\hline Pointer $(n=20)$ & 1 & - & 2 & 1 & 4 & 1 \\
\hline Setter $(n=22)$ & 1 & 1 & 1 & - & 3 & - \\
\hline Doberman $(n=12)$ & 1 & - & 2 & 1 & 3 & - \\
\hline Terrier $(n=20)$ & 3 & 1 & 3 & - & 5 & 2 \\
\hline Mongrel ( $\mathrm{n}=123)$ & 41 & - & 29 & - & 17 & - \\
\hline Total & 55 & 2 & 37 & 2 & 36 & 3 \\
\hline
\end{tabular}

R: Rural area, U: Urban Area

\section{Discussion and Conclusion}

The frequency of the serological positivity for $R$. ricketsii differs in various parts of the world. According to a research carried out in Southern Brasil, R. rickettsii positivity was found to be as $33.7 \%$ in dogs (22). However, in another study carried out in Minas Gerais, Brazil, it was $81.3 \%$ in dogs (26). In the study presented here, we found the serologic evidence of spotted fever group rickettsial infection in $54.0 \%$ of dogs examined. This difference might be related with various endemicity of the different areas and the frequent contact between humans, wild animals and domestic animals.

Based on the literature search that we carried out, there is no literature regarding to the detection of SFG Rickettsiae in dogs especially for $R$. ricketsii, in Turkey. In a study conducted on human blood samples in Black Sea Region of Turkey (24), it was reported that Spotted fever group anti-Rickettsia IgG antibody seropositivity were detected in 68/580 (11.7\%). In another case, Rickettsia ricketsii infection, causing septic shock associated adult respiratory distress syndrome in 72-yearold woman was reported (13). In these two researches given above, all samples were positive for IgM and IgG againts Rickettsia rickettsii antibodies by the microimmunoflouresence technique. These results show that SFG infections exist in our country.

We consider that Western Turkey might be an endemic area, because rural local areas are intense for the presence of ticks. The tick-borne diseases are frequently seen in the dogs found in the rural areas; however the number researches are poor for tick-borne diseases in these regions. The higher prevalence (64\%) found among rural dogs in this study was possibly linked to the higher diversity of ticks that these dogs were exposed to, in contrast to the urban area where very low prevalance (14\%) was established. In a BSF-endemic area in the state of São Paulo, where the tick vector (Amblyomma aureolatum) commonly infest dogs, 64\% (16/25) of the dogs contained reactive antibodies to Rickettsia spp. (20).

The present study examined canine sera against Rickettsia rickettsii in dogs in the Western Turkey. According to the literatures, three other Rickettsia species (R. rickettsii, R. parkeri, and R. felis) are known to occur in regions of Brazil and other South American countries $(5,7,9,15)$. We have detected $R$. ricketsii antibodies in canine sera and found seropositivity against Rickettsia ricketsii. This result shows the presence of SFG Rickettsia species in Western Turkey.

In southeastern Brazil, R. rickettsii is the most important human rickettsial agent, which causes a highly lethal, acute exantematic febrile disease locally called as Brazilian spotted fever (BSF). Lethality rates of BSF in southern Brazil are between $18-30 \%(1,3)$. The high 
prevalence $(64.0 \%)$ of Rickettsia rickettsii obtained in dogs with no clinical signs in the rural areas of Western Turkey may indicate the public health risk for human population who has close contact with dogs.

IFA is the gold standard method for serological diagnosis of rickettsial infections (10) but it presents some cross reactivity. Antibody titers against $R$. rickettsii are solely a proof of infection by a SFG rickettsia.

According to the research carried out in Minas Gerais, Brazil, a high prevalence was also found among dogs, $81.3 \%$ of them had antibody titers of 64 and 128 (26). This prevalence value is higher than others previously reported for dogs from BSF-endemic areas in Minas Gerais (13.68\%) and São Paulo (25 to 66\%) (8, $11,12)$. In this case, dogs can be responsible for bringing infected ticks to the home environment and increasing the risk of human infection. Besides, according to the research made in São Paulo, Brasil, 10 sera reacted positive to $R$. rickettsii among 164 rural dogs, and 1 sera reacted positive to $R$. rickettsii among 153 urban dogs in Monte Negro (9). This result shows correlation with the results of our study also. Because in our study, $54.0 \%$ $(135 / 250)$ of the dogs were seropositive and $43.2 \%$ $(108 / 250)$ of the dogs were seronegative for Rickettsia rickettsii. In addition, 2.8\% (7/250) of the dogs with titer $\geq 1: 64-<1: 256$ were found to be suspected for Rickettsia rickettsii. Besides, 7 (14.0\%) urban area dogs were seropositive with titer $\geq 1: 256$ and $128(64.0 \%)$ rural area dogs seropositive with titer $\geq 1: 256$ of Rickettsia rickettsii by IFA test.

In conclusion, the present study showed that the antibody titers against Rickettsia rickettsii agent in rural and urban dogs obtained in Western Turkey were at considerable levels. This situation may have great importance for public health hazard. The high prevalance of antibody titers in rural dogs shows that the Western Turkey is endemic by tick population and the exposure of disease to humans should also be evaluated in further studies. Our study might challenge to epidemiological researches in the future by the presence and prevalance of rickettsial diseases both in humans and other companion animals.

\section{References}

1. Angerami RN, Resende MR, Feltrin AF, Katz G, Nascimento EM, Stucchi RS, Silva LJ (2006): Brazilian spotted fever: a case series from an endemic area in southeastern Brazil: epidemiological aspects. Ann NY Acad Sci, 1078, 170-172.

2. Bowman DD, Little SE, Lorentzen L, Shields J, Sullivan MP, Carlin EP (2009): Prevalence and geographic distribution of Dirofilaria immitis, Borrelia burgdorferi, Ehrlichia canis, and Anaplasma phagocytophilum in dogs in the United States: results of a national clinic-based serologic survey. Vet Parasitol, 160, 138-148.
3. Calic SB, Barcellos-Rocha CM, Leite RC, Mafra CL (2005): Old and new human rickettsiosis in Minas Gerais state, Brazil. Ann NY Acad Sci, 1063, 356-357.

4. Foley JE, Brown RN, Gabriel MW, Henn J, Drazenovich N, Kasten R, Green SL, Chomel BB (2007): Spatial analysis of the exposure of dogs in rural north-coastal California to vectorbornepathogens. Vet Rec, 161, 653-657.

5. Guedes E, Leite RC, Prata MCA, Pacheco RC, Walker DH, Labruna MB (2005): Detection of Rickettsia rickettsii in the tick Amblyomma cajennense in a new Brazilian spotted feverendemic area in the state of Minas Gerais. Mem Inst Oswaldo Cruz, 100, 841-845.

6. Hinrichsen VL, Whitworth UG, Breitsschwerdt EB, Heqarty BC, Mather TN (2001): Assessing the association between the geographic distribution of deer ticks and seropositivity rates to various tick-transmitted disease organisms in dogs. J Am Vet Med Assoc, 218, 1092-1097.

7. Horta MC, Labruna MB, Pinter A, Linardi PM, Schumaker TTS (2007): Rickettsia infection in five areas of the State of São Paulo, Brazil. Mem Inst Oswaldo Cruz, 102, 793-801.

8. Horta MC, Labruna MB, Sangioni LA (2004): Prevalence of antibodies to spotted fever group rickettsiae in humans and domestic animals in a Brazilian spotted fever endemic area in the state of São Paulo, Brazil: serological evidence for infection by Rickettsia rickettsii and another spotted fever group rickettsia. Amer J Trop Med Hyg,; 71, 93-97.

9. Labruna MB, Pacheco RC, Richtzenhain LJ, Szabo MP (2007): Isolation of Rickettsia rhipicephali and Rickettsia bellii from ticks Haemaphysalis juxtakochi in the state of Sao Paulo, Brazil. Appl Environ Microbiol, 73, 869-873.

10. LaScola B, Raoult D (1997): Laboratory diagnosis of rickettsioses: current approaches to diagnosis of old and new rickettsial diseases. J Clin Microbiol, 35, 2715-2727.

11. Lemos ERS, Machado RD, Coura JR, Guimarães MA, Chagas N (1996): Epidemiological aspects of the Brazilian spotted fever: serological survey of dogs and horses in an endemic area in the state of São Paulo, Brazil. Rev Inst Med Trop S Paulo, 38, 427-430.

12. Lemos ERS, Machado RD, Coura JR (1994): Rocky Mountain spotted fever in an endemic area in Minas Gerais, Brazil. Mem Inst Oswaldo Cruz, 89, 497-501.

13. Memiş D, Sapolya O, Tasdoğan M, Yucel T, Vatan İ (2007): Rickettsia ricketsii infection presenting as septic shock and adult respiratory distress syndrome. J Chinese Clinical Medicine, 2, 341-343.

14. Nicholson WL, Allen KE, McQuiston JH, Breitsschwerdt EB, Little SE (2010): The increasing recognation of ricketsial pathogens in dogs and people. Trends Prasitol, 26, 205-212.

15. Pacheco RC, Venzal JM, Richtzenhain LJ, Labruna MB (2006): Rickettsia parkeri in Uruguay. Emerg Infec Dis, 12, 1804-1805.

16. Paddock CD, Brenner O, Vaid C, Boyd DB, Berg JM, Joseph RJ, Zaki SR, Childs JE (2002): Short report: concurrent Rocky Mountain spotted fever in a dog and its owner. Am J Trop Med Hyg, 66, 197- 199. 
17. Parola P, Davoust B, Raoult D (2005a): Tick and fleaborne rickettsial emerging zoonoses. Vet Res, 36, 469-492.

18. Parola P, Paddock CD, Raoult D (2005b): Tick borne rickettsioses around the world: emerging diseases challenging old concepts. Clin Microbiol Rev, 18, 719756.

19. Parola P, Raoult D (2001): Ticks and tickborne bacterial diseases in humans: an emerging infectious threat. Clin Infect Dis, 32, 897-928.

20. Pinter A, Labruna MB (2006): Isolation of Rickettsia rickettsii and Rickettsia bellii in cell culture from the tick Amblyomma aureolatum in Brazil. Ann NY Acad. Sci, 1078, 523-529.

21. Raoult D, Roux V (1997): Rickettsioses as paradigms of new or emerging infectious diseases. Clin Microbiol Rev, 10, 694-719.

22. Saito TB, Pacheco NA, Ferreira RC, Pappen FG, Farias NA, Larsson CE, Labruna MB (2008): Canine infection by rickettsiae and ehrlichiae in southern Brazil. Am J Trop Med Hyg, 79, 102-108.

23. Solano-Gallego L, Kidd L, Trotta M, Di MArco M, Caldin M, Furlanello T, Breitschwerdt E (2006): Febrile illness associated with Rickettsia conorii infection in dogs from Sicily. Emerg Infect Dis, 12, 1985-2188.
24. Tekin A, Gözalan A, Çöplü N, Yılmaz G, Köksal İ, Esen B, Ertek M (2010): The seropositivity and risk factors for rickettsial infections in selected areas from Black Sea Region of Turkey. Dicle Medical J, 37, 204-210.

25. The Center for Food Security \& Public Health (CFSPH) (2005): Rocky Mountain Spotted Fever, Iowa State University. Available at, accessed on 20 October 2012, http://www.cfsph.iastate.edu, p 1-5.

26. Vianna MCB, Horta MC, Sangioni LA, Cortez A, Soares RM, Mafra CL, Galvao MAM, Labruna MB, Gennari SM (2008): Ricketsial Spotted Fever in Capoeirao Village, Itabira, Minas Gerais, Brazil. Rev Inst Med Trop S Paulo, 50, 297-301.

Geliş tarihi: 02.12.2012 / Kabul tarihi: 28.03.2013

Address for correspondence:

Dr. Sukru Kirkan

Bacteriology and Serology Division of the Department of Microbiology,

Faculty of Veterinary Medicine, Adnan Menderes University, Isikli, 09016, Aydin/Turkey. e-mail: skirkan@adu.edu.tr 